\title{
Sevier-Laramide deformation of the continental interior from calcite twinning analysis, west-central North America
}

\author{
John P. Craddock ${ }^{\mathrm{a}, *}$, Ben A. van der Pluijm ${ }^{\mathrm{b}}$ \\ ${ }^{a}$ Geology Department, Macalester College, St. Paul, Minnesota 55105, USA \\ ${ }^{b}$ Department of Geological Sciences, University of Michigan, Ann Arbor, Michigan 48109, USA
}

Received 17 March 1989; revised version received 20 May 1998; accepted 23 July 1998

\begin{abstract}
Paleozoic-Mesozoic carbonates that cover cratonic western North America contain a regional layer-parallel shortening (LPS) fabric that is preserved by mechanically twinned calcite. Shortening directions are generally parallel to the Sevier thrust-transport direction (E-W) in carbonates of the Idaho-Wyoming portion of the thrust belt and within carbonates as far as $2000 \mathrm{~km}$ into the plate interior. The inferred calcite twinning differential stress magnitudes generally decrease across the thrust belt, and decrease exponentially away from the orogenic front into the craton. Synorogenic calcite cements and veins preserve a distinct twinning deformation history: in the thrust belt, twinning strains commonly record local, out-of-transport piggyback strain events with high differential stresses $(<150 \mathrm{MPa})$, whereas in Laramide uplifts and adjacent basins as far east as the Black Hills, twinned vein calcite preserves a sub-horizontal, N-S-shortening strain, with differential stress magnitudes that decrease to the east. Deformation of the plate interior during the Sevier orogeny was dominated by $\mathrm{E}-\mathrm{W}$ contraction at the plate margin, which changed into dominantly oblique contraction $(\sim \mathrm{N}-\mathrm{S}$ shortening) along western North America during the younger, basement-involved Laramide event. (c) 1999 Elsevier Science B.V. All rights reserved.
\end{abstract}

Keywords: calcite twinnning; Sevier-Laramide orogen; plate interior

\section{Introduction}

Plate convergence and collision characteristically result in intense deformation belts along plate margins (e.g., the formation of fold-thrust belts), but stable continental interiors also experience effects of plate interactions (van der Pluijm et al., 1997). The eastern midcontinent region of the U.S.A. is perhaps the best-studied example of plate interior

\footnotetext{
*Corresponding author. Tel.: +1 651696 6620; Fax: +1 651
} 696 6432; E-mail: craddock@macalester.edu deformation, displaying deformation features that include folds and detachments (Rodgers, 1963; Gwinn, 1964; Wiltschko and Chapple, 1977; Davis and Engelder, 1985; Anderson, 1988), joint and cleavage fabrics (Nickelson, 1966; Geiser and Engelder, 1983), deformed fossils (Engelder and Engelder, 1977; Engelder and Geiser, 1980), recurrent faulting (Onasch and Kahle, 1991), and calcite twinning (Engelder, 1979a,b; Gasteiger, 1980; Craddock and van der Pluijm, 1989; Jackson et al., 1989).

In this paper we extend our earlier calcite twinning work in the eastern U.S. midcontinent (Crad- 


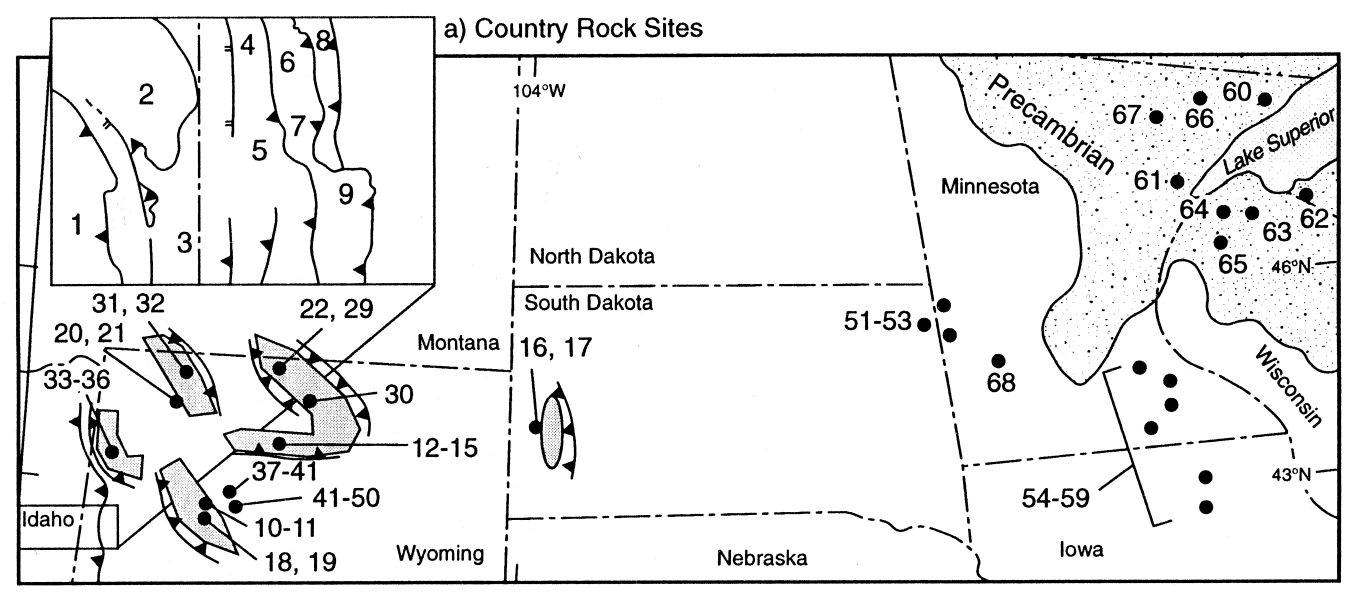

b) Vein Sites
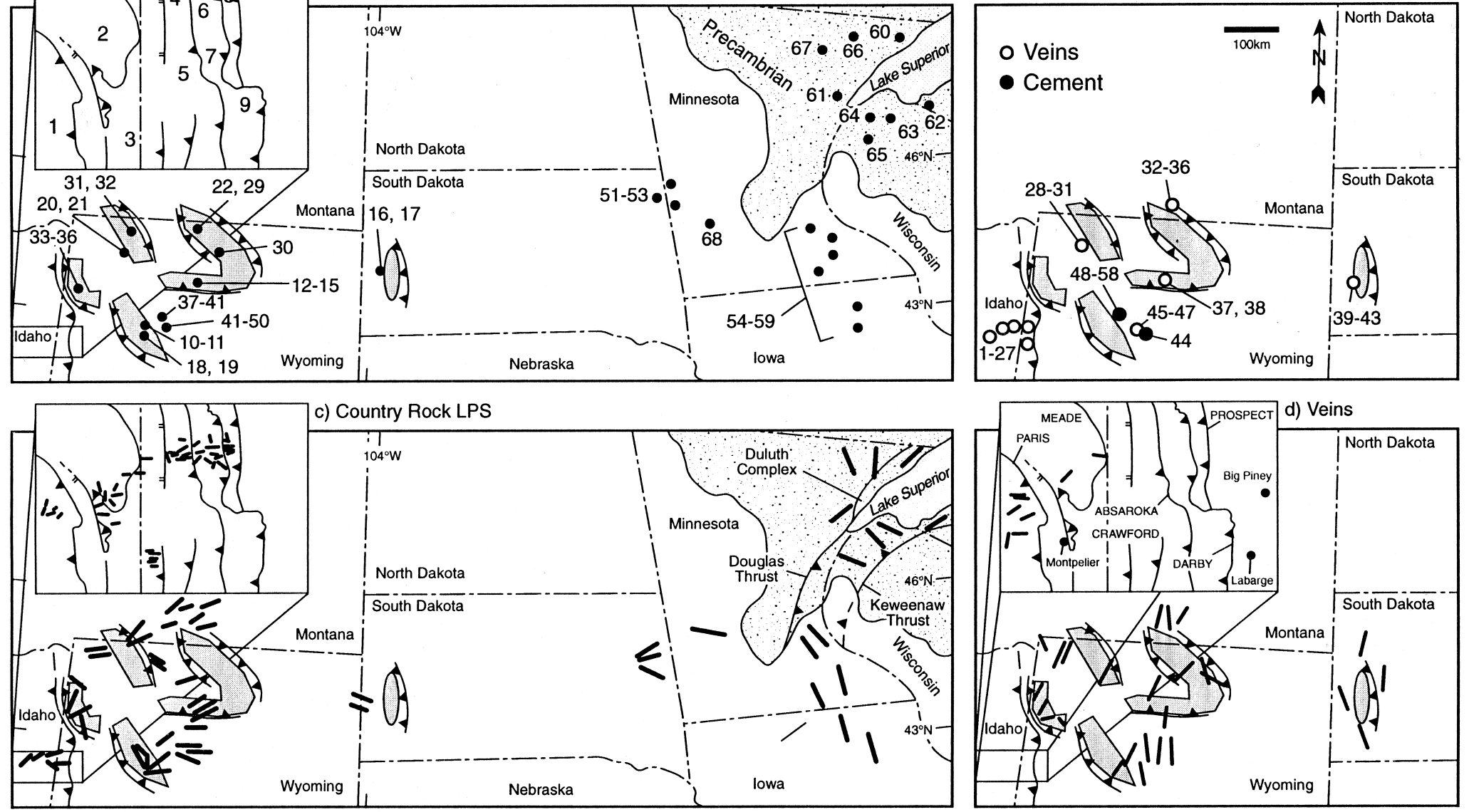

Fig. 1. (a) Country rock sample sites (see Table 1). Inset map includes strain data from the Idaho-Wyoming thrust belt (Craddock et al., 1988; Craddock, 1992). (b) Vein and cement sample sites. (c) Country rock calcite twinning strain results (see Table 2), with shortening axes plotted for the Idaho-Wyoming thrust belt (inset), Laramide uplifts, foreland, and older, adjacent tectonic provinces. (d) Calcite twinning strain results for synorogenic veins, with shortening axes plotted for the Idaho-Wyoming thrust belt (inset), Laramide uplifts and the foreland. 
dock et al., 1993) to a characterization of regional deformation patterns in the Sevier-Laramide belt and the western portion of cratonic North America. This study of 210 calcite strain analyses (Fig. 1a,b) adds 18 new limestone and 18 vein calcite strain analyses to the existing data base of 136 country rock (108 Sevier thrust belt, 25 Laramide, and 3 foreland) and 38 vein or cement (27 Sevier thrust belt and 11 Laramide) analyses. Our regional analysis utilizes the chronology of twinning in different calcite elements (limestones, cements, veins) for the Sevier thrust belt and foreland, and younger, Laramide structures, which are distinct from results in older, adjacent tectonic provinces (fifteen representative strain analyses).

\section{Methods}

\subsection{Calcite twinning}

Calcite twins mechanically at low differential stresses ( $10 \mathrm{MPa}$; see Lancome and Laurent, 1996; Ferrill, 1998), and is largely independent of temperature and normal stress magnitudes in the uppermost crust. Twinning is possible along three glide planes and calcite strain-hardens once twinned; further twinning is possible in a crystal along either of the remaining two $e\{0112\}$ planes at higher stress levels, provided that stress is oriented $>45^{\circ}$ from the initial stress orientation (Teufel, 1980). The application of twinned calcite to structural and tectonic problems has been primarily restricted to studies of limestones (e.g., Groshong, 1975; Engelder, 1979a; Spang and Groshong, 1981; Wiltschko et al., 1985; Craddock et al., 1993), calcite veins (e.g., Kilsdonk and Wiltschko, 1988), or, more rarely, marbles (e.g., Craddock et al., 1991). Craddock and Pearson (1994) and Craddock et al. (1997) have studied twinning strains in secondary calcite of basalts from DSDP Hole 433C and the Proterozoic Keweenaw rift, respectively. Rowe and Rutter (1990) and Burkhard (1993) have recently reviewed the variety of methods applied to utilizing twinned calcite in a host of geologic environments.

Paleostress (paleopiezometry of Engelder, 1993) responsible for twinning can be calculated in terms of their compressional (or tensile) orientation
(Turner, 1953) and magnitude (Jamison and Spang, 1976; Rowe and Rutter, 1990). Strain ellipsoid axis orientations are computed using the calcite strain gauge (Groshong, 1972, 1974) and are quite accurate for strains ranging from 1 to $17 \%$ (Groshong et al., 1984), although strain magnitudes vary greatly depending on lithology, grain size, porosity, etc., and are a function of twin thickness. Thin twins $(\sim 0.5$ $\mu \mathrm{m})$ are dominant in our sample suite, which is characteristic of calcite deformed below $200^{\circ} \mathrm{C}$ (Ferrill, 1991, 1998). The calcite strain gauge technique also computes positive and negative expected values (PEV and NEV, respectively) for all the twins in a given thin section. A NEV for a twinned grain indicates that this grain was unfavorably oriented relative to the stress field that caused the majority of the grains in a given thin section to twin. A high percentage of negative expected values $(>40 \%)$ indicates that a second, non-coaxial twinning event occurred and these two twinning strains (PEV and NEV groups, respectively) can be analyzed separately.

\section{Results}

\subsection{Idaho-Wyoming thrust belt}

Calcite strain results from limestones in the Idaho-Wyoming thrust belt preserve a layer-parallel, thrust transport-parallel twinning fabric (Fig. 1a,c) that has been used to interpret dextral transpression associated with the progressive shortening and rotation within this thrust belt (Craddock, 1992). A layer-parallel, roughly E-W shortening fabric is also found in limestones across the foreland as far east as Minnesota (see below). Synorogenic calcite veins across the thrust belt record high differential stresses and strain magnitudes $(90 \mathrm{MPa},-6 \%$, respectively) in a variety of orientations (Fig. 1c), which reflect local complexities of piggyback thrusting rotations (Budai and Wiltschko, 1987; Craddock and van der Pluijm, 1988; see also Allmendinger, 1982; Kraig and Wiltschko, 1987; Kraig et al., 1987; Apotria, 1990, 1995). Inferred differential stress results between Idaho and Minnesota are based on the technique of Jamison and Spang (1976), and are summarized in van der Pluijm et al. (1997). 
Table 1

Sevier thrust belt, foreland and Laramide uplifts

\begin{tabular}{|c|c|c|c|c|c|}
\hline Sample & Age & $\begin{array}{l}\text { NEVs } \\
(\%)\end{array}$ & $\begin{array}{l}e 1 \text { trend/plunge } \\
\left({ }^{\circ}\right)\end{array}$ & $\begin{array}{l}e 1 \\
(\%)\end{array}$ & Comment \\
\hline \multicolumn{6}{|c|}{ Idaho-Wyoming thrust belt (140-40 Ma) } \\
\hline 1 & $\mathrm{C}$ & 12 & $56^{\circ}$ & -5.5 & IW thrust belt, Paris sheet ${ }^{\mathrm{a}}$ \\
\hline 2 & M & 16 & $63^{\circ}$ & -5.3 & IW thrust belt, Meade sheet ${ }^{\mathrm{a}}$ \\
\hline 3 & $\mathrm{~J}, \mathrm{~K}$ & 3 & $84^{\circ}$ & -3.5 & IW thrust belt, Crawford sheet ${ }^{\mathrm{a}}$ \\
\hline 4 & M & 19 & $65^{\circ}$ & -3.5 & IW belt, N. Absaroka sheet ${ }^{c}$ \\
\hline 5 & $\mathrm{C}, \mathrm{J}$ & 9 & $93^{\circ}$ & -3.9 & IW belt; central Absaroka sheet ${ }^{a}$ \\
\hline 6 & $\mathrm{~J}$ & 19 & $70^{\circ}$ & -3.7 & IW belt; N. Darby sheet ${ }^{\mathrm{c}}$ \\
\hline 7 & $\mathrm{M}-\mathrm{J}$ & 17 & $105^{\circ}$ & -5.5 & IW belt; central Darby sheet ${ }^{\mathrm{a}}$ \\
\hline 8 & $\mathrm{~J}$ & 23 & $76^{\circ}$ & -3.9 & IW belt, N. Prospect sheet ${ }^{\mathrm{c}}$ \\
\hline 9 & $\mathrm{M}-\mathrm{J}$ & 4 & $90^{\circ}$ & -5 & IW belt; central Prospect sheet ${ }^{a, b}$ \\
\hline \multicolumn{6}{|c|}{ Laramide uplifts $(\sim 60-40 \mathrm{Ma})$} \\
\hline 10 & $\mathrm{~J}$ & 10 & $115^{\circ}, 45^{\circ}$ & -4 & Wind River Rge; ${ }^{c}[\# 3]$ \\
\hline 11 & $\mathrm{M}$ & 4 & $155^{\circ}, 5^{\circ}$ & -2.7 & Wind River Rge; ${ }^{\mathrm{c}}[\# 31]$ \\
\hline 12 & $\mathrm{O}$ & 10 & $35^{\circ}$ & -1.7 & Wind River Canyon \\
\hline 13 & $\mathrm{C}$ & 13 & $54^{\circ}$ & -2.9 & Wind River Canyon \\
\hline 14 & $\mathrm{M}$ & 14 & $15^{\circ}$ & -8.4 & Wind River Canyon \\
\hline 15 & $\mathrm{~J}$ & 0 & $94^{\circ}$ & -8.3 & S. Wind River Canyon \\
\hline 16 & $\mathrm{D}$ & 13 & $131^{\circ}$ & -2.3 & Black Hills \\
\hline 17 & $\mathrm{M}$ & 34 & $120^{\circ}$ & -1.1 & Black Hills \\
\hline 18 & $\mathrm{C}$ & 7 & $45^{\circ}$ & -2.2 & Sinks Canyon, Wind River Rge. \\
\hline 19 & $\mathrm{M}$ & 0 & $70^{\circ}$ & -1.8 & Sinks Canyon, Wind River Rge. \\
\hline 20 & $\mathrm{M}$ & 0 & $90^{\circ}, 10^{\circ}$ & -6.3 & Heart Mtn. footwall \\
\hline 21 & $\mathrm{M}$ & 6 & $95^{\circ}, 1^{\circ}$ & -2.6 & Heart Mtn. footwall \\
\hline 22 & $\mathrm{M}$ & 8 & $47^{\circ}$ & -4.3 & Bighorn Mtns. $^{d}$ \\
\hline 23 & M & 32 & $53^{\circ}$ & -7.7 & Bighorn Mtns. ${ }^{\mathrm{d}}$ \\
\hline 24 & $\mathrm{M}$ & 8 & $51^{\circ}$ & -7.4 & Bighorn Mtns. ${ }^{\mathrm{d}}$ \\
\hline 25 & $\mathrm{M}$ & 0 & $45^{\circ}$ & -5.3 & Bighorn Mtns. ${ }^{d}$ \\
\hline 26 & $\mathrm{M}$ & 11 & $160^{\circ}$ & -8.3 & Bighorn Mtns. ${ }^{\mathrm{d}}$ \\
\hline 27 & $\mathrm{M}$ & 18 & $82^{\circ}$ & -4.5 & Bighorn Mtns. ${ }^{\mathrm{d}}$ \\
\hline 28 & $\mathrm{M}$ & 7 & $21^{\circ}$ & -4.1 & Bighorn Mtns. ${ }^{d}$ \\
\hline 29 & $\mathrm{O}$ & 26 & $40^{\circ}$ & -6 & Bighorn Mtns. ${ }^{\mathrm{d}}$ \\
\hline 30 & $\mathrm{O}$ & 0 & $60^{\circ}$ & -1.1 & Bighorn Mtns. \\
\hline 31 & $\mathrm{C}$ & 4 & $30^{\circ}$ & -1.2 & Beartooth Mtns. \\
\hline 32 & $\mathrm{O}$ & 8 & $70^{\circ}$ & -4.1 & Beartooth Mtns. \\
\hline 33 & $\mathrm{M}$ & 0 & $300^{\circ}, 55^{\circ}$ & -8.2 & Teton's; Cache Crk. thrust ${ }^{\mathrm{e}}$ \\
\hline 34 & $\mathrm{M}$ & 100 & $170^{\circ}, 67^{\circ}$ & -2.9 & Teton's; Cache Crk. thrust ${ }^{\mathrm{e}}$ \\
\hline 35 & $\mathrm{M}$ & 8 & $183^{\circ}$ & -6.3 & Teton's; Cache Crk. thrust ${ }^{\mathrm{e}}$ \\
\hline 36 & M & 0 & $173^{\circ}$ & -2.5 & Teton's; Cache Crk. thrust ${ }^{\mathrm{e}}$ \\
\hline \multicolumn{6}{|c|}{ Sevier-Laramide basins (140-40 Ma) } \\
\hline 37 & $\mathrm{~J}$ & 6 & $68^{\circ}, 8^{\circ}$ & -6.2 & Derby Dome ${ }^{\mathrm{i}}$ \\
\hline 38 & $\mathrm{~J}$ & 3 & $146^{\circ}, 4^{\circ}$ & -1.7 & Derby Dome ${ }^{\mathrm{i}}$ \\
\hline 39 & $\mathrm{~J}$ & 2 & $113^{\circ}, 25^{\circ}$ & -3.14 & Derby Dome ${ }^{\mathrm{i}}$ \\
\hline 40 & $\mathrm{~J}$ & 4 & $135^{\circ}, 17^{\circ}$ & -2.3 & Derby Dome ${ }^{\mathrm{i}}$ \\
\hline 41 & $\mathrm{~J}$ & 16 & $101^{\circ}, 12^{\circ}$ & -0.34 & Derby Dome $^{\mathrm{i}}$ \\
\hline 42 & $\mathrm{~J}$ & 8 & $260^{\circ}, 10^{\circ}$ & -3.6 & Wind River basin folds ${ }^{c}[\# 28]$ \\
\hline 43 & $\mathrm{~J}$ & 2 & $40^{\circ}, 55^{\circ}$ & -4.2 & Wind River basin folds ${ }^{c}$ [\#27] \\
\hline 44 & $\mathrm{~J}$ & 23 & $215^{\circ}, 15^{\circ}$ & -2.2 & Wind River basin folds ${ }^{c}[\# 25]$ \\
\hline 45 & $\mathrm{~J}$ & 14 & $50^{\circ}, 45^{\circ}$ & -4.1 & Wind River basin folds ${ }^{\mathrm{c}}[\# 23]$ \\
\hline 46 & $\mathrm{~J}$ & 10 & $175^{\circ}, 70^{\circ}$ & -4.5 & Wind River basin folds ${ }^{c}$ [\#19] \\
\hline 47 & $\mathrm{~J}$ & 2 & $180^{\circ}, 70^{\circ}$ & -4.4 & Wind River basin folds ${ }^{c}$ [\#18] \\
\hline 48 & $\mathrm{~J}$ & 4 & $85^{\circ}, 15^{\circ}$ & -3 & Wind River basin folds ${ }^{c}[\# 12]$ \\
\hline
\end{tabular}


Table 1 (continued)

\begin{tabular}{|c|c|c|c|c|c|}
\hline Sample & Age & $\begin{array}{l}\text { NEVs } \\
(\%)\end{array}$ & $\begin{array}{l}e 1 \text { trend/plunge } \\
\left({ }^{\circ}\right)\end{array}$ & $\begin{array}{l}e 1 \\
(\%)\end{array}$ & Comment \\
\hline 49 & $\mathrm{~J}$ & 8 & $30^{\circ}, 30^{\circ}$ & -5.8 & Wind River basin folds ${ }^{c}[\# 10]$ \\
\hline 50 & $\mathrm{~J}$ & 6 & $300^{\circ}, 10^{\circ}$ & -3.5 & Wind River basin folds ${ }^{c}[\# 9]$ \\
\hline 51 & $\mathrm{~K}$ & 30 & $81^{\circ}$ & -2.7 & Greenhorn Limestone, $\mathrm{MN}^{\mathrm{f}}$ \\
\hline 52 & $\mathrm{~K}$ & 20 & $67^{\circ}$ & -1.1 & Greenhorn Limestone, $\mathrm{MN}^{\mathrm{f}}$ \\
\hline 53 & $\mathrm{~K}$ & 0 & $130^{\circ}$ & -3.5 & Greenhorn Limestone, $\mathrm{MN}^{\mathrm{f}}$ \\
\hline \multicolumn{6}{|c|}{ Older, adjacent tectonic provinces: } \\
\hline \multicolumn{6}{|c|}{ Appalachian-Ouachita foreland $(\sim 240 \mathrm{Ma})$} \\
\hline 54 & 0 & 0 & $149^{\circ}$ & -4.2 & Southeast Minnesota ${ }^{\mathrm{f}}$ \\
\hline 55 & 0 & 22 & $178^{\circ}$ & -2.8 & Southeast Minnesota ${ }^{\mathrm{f}}$ \\
\hline 56 & $\mathrm{D}$ & 12 & $154^{\circ}$ & -1.6 & Southeast Minnesota ${ }^{\mathrm{f}}$ \\
\hline 57 & $\mathrm{D}$ & 8 & $186^{\circ}$ & -2.2 & Southeast Minnesota ${ }^{\mathrm{f}}$ \\
\hline 58 & $\mathrm{D}$ & 36 & $177^{\circ}$ & -0.93 & Northeast Iowa ${ }^{\mathrm{f}}$ \\
\hline 59 & $\mathrm{D}$ & 0 & $178^{\circ}$ & -0.45 & Northeast Iowa ${ }^{\mathrm{f}}$ \\
\hline \multicolumn{6}{|c|}{ Keweenaw Province $(\sim 1.0 \mathrm{Ga})$} \\
\hline 60 & $\mathrm{P} 2$ & 10 & $55^{\circ}$ & -9.8 & Amygdaloidal basalt $\mathrm{g}$ \\
\hline 61 & $\mathrm{P} 2$ & 12 & $42^{\circ}$ & -3.5 & Amygdaloidal basalt ${ }^{\mathrm{g}}$ \\
\hline 62 & $\mathrm{P} 2$ & 20 & $50^{\circ}$ & -5.2 & Amygdaloidal basalt ${ }^{\mathrm{g}}$ \\
\hline 63 & $\mathrm{P} 2$ & 22 & $151^{\circ}$ & -5.7 & Calcite veins in basalt $\mathrm{g}$ \\
\hline 64 & $\mathrm{P} 2$ & 26 & $150^{\circ}$ & -1.2 & Calcite veins in basalt ${ }^{\mathrm{g}}$ \\
\hline 65 & $\mathrm{P} 2$ & 14 & $162^{\circ}$ & -1.9 & Calcite veins in basalt $\mathrm{g}$ \\
\hline \multicolumn{6}{|c|}{ Kenora-Kabetogama mafic dikes $(\sim 2.06 \mathrm{Ga})$} \\
\hline 66 & $\mathrm{P} 1$ & 6 & $10^{\circ}$ & -7.7 & Dike-margin veins ${ }^{\mathrm{h}}$ \\
\hline 67 & $\mathrm{P} 1$ & 8 & $171^{\circ}$ & -5.7 & Dike-margin veins ${ }^{\mathrm{h}}$ \\
\hline 68 & $\mathrm{P} 1$ & 11 & $322^{\circ}$ & -4.5 & Dike-margin veins ${ }^{\mathrm{h}}$ \\
\hline
\end{tabular}

${ }^{\text {a }} 60$ samples from Craddock (1992).

b 18 samples from Kraig and Wiltschko (1987), excluding 30N and 19P.

${ }^{c} 13$ samples from Willis and Groshong (1993).

d 8 samples from Hennings (1986a); 10 samples from Carson (1988).

e 33 samples from Craddock et al. (1988).

${ }^{\mathrm{f}} 6$ samples from Craddock et al. (1993).

g 6 samples from Craddock et al. (1997); 3 amygdule fillings, 3 veins.

${ }^{\mathrm{h}}$ Craddock and Moshoian, 1995; Wirth and Vervoort, 1995; Kropf et al., 1993.

i 5 distal limb samples; Relle and Craddock, 1997.

(Key: P1 = Early Precambrian; P2 = Late Precambrian; C = Cambrian; O = Ordovician; D = Devonian; $\mathrm{M}=\mathrm{Mississippian;} \mathrm{J}=$ Jurassic; $\mathrm{K}=$ Cretaceous.

\subsection{Laramide uplifts and basins}

An array of 44 samples in Paleozoic limestones and veins from the Beartooth, Wind River, Owl Creek, Bighorn and Black Hills Ranges complement earlier work in the Bighorn Mountains (Hennings, 1986a,b; Carson, 1988), in the Teton-Gros Ventre Range (Craddock et al., 1988), and in the Wind River Range and Wind River basin (Willis and Groshong, 1993). New strain analyses from the Heart Mountain footwall (Neilson et al., 1997) and Derby dome
(Relle and Craddock, 1997) are also included (Table 1, Fig. 1c).

Calcite strain analyses from limestones in the Laramide uplifts preserve a regionally consistent $\sim$ ENE-WSW LPS fabric despite, in some cases, uplift and thrust transport from north to south (e.g., Owl Creek Range; Varga, 1993). Strain analyses from the folds flanking the Wind River Range (Willis and Groshong, 1993; ten samples) record an E-W LPS fabric, as well as significant passive rotation of the pre-fold twinning strain ellipsoid during folding and 
Table 2

Sevier-Laramide calcite cements and veins

\begin{tabular}{|c|c|c|c|c|c|c|}
\hline Sample & Cement or vein & Strike and dip & $\begin{array}{l}\text { NEVs } \\
(\%)\end{array}$ & $\begin{array}{l}e 1 \text { trend/plunge } \\
\left({ }^{\circ}\right)\end{array}$ & $\begin{array}{l}e 1 \\
(\%)\end{array}$ & Comment \\
\hline \multicolumn{7}{|c|}{ Idaho-Wyoming Thrust Belt } \\
\hline 1 & Vein & $47^{\circ}, 90^{\circ}$ & 15 & $50^{\circ}, 87^{\circ}$ & -13.6 & Paris sheet ${ }^{\mathrm{a}}$ \\
\hline 2 & Vein & $320^{\circ}, 45^{\circ} \mathrm{W}$ & 18 & $260^{\circ}, 30^{\circ}$ & -3.2 & Paris sheet \\
\hline 3 & Vein & $51^{\circ}, 90^{\circ}$ & 13 & $45^{\circ}, 90^{\circ}$ & -3.1 & Paris sheet \\
\hline 4 & Vein & $0^{\circ}, 22^{\circ} \mathrm{W}$ & 0 & $37^{\circ}, 20^{\circ}$ & -5.7 & Paris sheet \\
\hline 5 & Vein & $20^{\circ}, 35^{\circ} \mathrm{NW}$ & 22 & $302^{\circ}, 45^{\circ}$ & -1.7 & Meade sheet \\
\hline 6 & Vein & $350^{\circ}, 56^{\circ} \mathrm{SW}$ & 10 & $271^{\circ}, 60^{\circ}$ & -4.8 & Meade sheet \\
\hline 7 & Vein & $330^{\circ}, 43^{\circ} \mathrm{NE}$ & 32 & $43^{\circ}, 15^{\circ}$ & -5.6 & Meade sheet \\
\hline 8 & Vein & $88^{\circ}, 12^{\circ} \mathrm{S}$ & 33 & $93^{\circ}, 5^{\circ}$ & -3 & Meade sheet \\
\hline 9 & Vein & $90^{\circ}, 40^{\circ} \mathrm{S}$ & 12 & $274^{\circ}, 13^{\circ}$ & -4.4 & Meade sheet \\
\hline 10 & Vein & $85^{\circ}, 12^{\circ} \mathrm{N}$ & 17 & $270^{\circ}, 10^{\circ}$ & -8.9 & Meade sheet \\
\hline 11 & Vein & $0^{\circ}, 45^{\circ} \mathrm{W}$ & 25 & $22^{\circ}, 12^{\circ}$ & -2.3 & Crawford sheet \\
\hline 12 & Vein & $20^{\circ}, 23^{\circ} \mathrm{W}$ & 12 & $93^{\circ}, 85^{\circ}$ & -3.7 & Crawford sheet \\
\hline 13 & Vein & $285^{\circ}, 75^{\circ}$ & 29 & $8^{\circ}, 12^{\circ}$ & -6.4 & Absaroka sheet \\
\hline 14 & Vein & $338^{\circ}, 90^{\circ}$ & 27 & $340^{\circ}, 18^{\circ}$ & -2 & Absaroka sheet \\
\hline 15 & Vein & $47^{\circ}, 90^{\circ}$ & 23 & $225^{\circ}, 70^{\circ}$ & -1.8 & Absaroka sheet \\
\hline 16 & Vein & $320^{\circ}, 75^{\circ} \mathrm{S}$ & 27 & $90^{\circ}, 8^{\circ}$ & -5.9 & Absaroka sheet \\
\hline 17 & Vein & $45^{\circ}, 90^{\circ}$ & 29 & $45^{\circ}, 5^{\circ}$ & -12.7 & Absaroka sheet ${ }^{b}$ \\
\hline 18 & Vein & $0^{\circ}, 90^{\circ}$ & No data & $45^{\circ}, 50^{\circ}$ & No data & Absaroka sheet ${ }^{\mathrm{c}}[\mathrm{Grp} \mathrm{I}]$ \\
\hline 19 & Vein & $90^{\circ}, 90^{\circ}$ & No data & $265^{\circ}, 20^{\circ}$ & No data & Absaroka sheet ${ }^{c}[$ Grp II] \\
\hline 20 & Vein & $90^{\circ}, 90^{\circ}$ & No data & $340^{\circ}, 30^{\circ}$ & No data & Absaroka.sheet ${ }^{\mathrm{c}}[\mathrm{Grp}$ II] \\
\hline 21 & Vein & $90^{\circ}, 90^{\circ}$ & No data & $40^{\circ}, 15^{\circ}$ & No data & Absaroka sheet $^{c}[$ Grp II] \\
\hline 22 & Vein & $90^{\circ}, 90^{\circ}$ & No data & $85^{\circ}, 10^{\circ}$ & No data & Absaroka sheet ${ }^{\mathrm{c}}[$ Grp II] \\
\hline 23 & Vein & $90^{\circ}, 90^{\circ}$ & No data & $90^{\circ}, 20^{\circ}$ & No data & Absaroka sheet ${ }^{\mathrm{c}}[\mathrm{Grp}$ II] \\
\hline 24 & Vein & $90^{\circ}, 90^{\circ}$ & No data & $100^{\circ}, 15^{\circ}$ & No data & Absaroka sheet ${ }^{\mathrm{c}}[\mathrm{Grp}$ II] \\
\hline 25 & Vein & $93^{\circ}, 72^{\circ} \mathrm{N}$ & 16 & $181^{\circ}, 3^{\circ}$ & -8.1 & Darby sheet \\
\hline 26 & Vein & $80^{\circ}, 90^{\circ}$ & 5 & $262^{\circ}, 11^{\circ}$ & -8.5 & Darby sheet \\
\hline 27 & Vein & $0^{\circ}, 0^{\circ}$ & 10 & $90^{\circ}, 3^{\circ}$ & -7.9 & Prospect sheet \\
\hline \multicolumn{7}{|c|}{ Laramide Uplifts } \\
\hline 28 & Vein & $0^{\circ}, 90^{\circ}$ & 22 & $194^{\circ}, 7^{\circ}$ & -3.9 & Heart Mtn. footwall ${ }^{\mathrm{e}}$ \\
\hline 29 & Vein & $13^{\circ}, 90^{\circ}$ & 12 & $12^{\circ}, 20^{\circ}$ & -1.7 & Heart Mtn. footwall ${ }^{\mathrm{e}}$ \\
\hline 30 & Vein & $305^{\circ}, 90^{\circ}$ & 0 & $285^{\circ}, 7^{\circ}$ & -7.5 & Heart Mtn. footwall ${ }^{\mathrm{e}}$ \\
\hline 31 & Vein & $0^{\circ}, 90^{\circ}$ & 22 & $195^{\circ}, 10^{\circ}$ & -3.7 & Rattlesnake Mtn. \\
\hline 32 & Vein & $0^{\circ}, 90^{\circ}$ & 10 & $30^{\circ}, 10^{\circ}$ & -1.6 & W. Bighorn Mtns. \\
\hline 33 & Vein & $0^{\circ}, 90^{\circ}$ & 18 & $350^{\circ}, 7^{\circ}$ & -4.1 & E. Bighorn Mtns. \\
\hline 34 & Vein & $110^{\circ}, 90^{\circ}$ & 15 & $110^{\circ}, 30^{\circ}$ & -4.1 & E. Bighorn Mtns. \\
\hline 35 & Vein & no data & 9 & $197^{\circ}, 65^{\circ}$ & -2.35 & Bighorn Mtns $\mathrm{g}$ \\
\hline 36 & Vein & no data & 14 & $159^{\circ}, 12^{\circ}$ & -2.78 & Bighorn Mtns. ${ }^{\mathrm{g}}$ \\
\hline 37 & Vein & $330^{\circ}, 90^{\circ}$ & 11 & $20^{\circ}$ & -3.6 & Owl Creek Mtns. \\
\hline 38 & Vein & $330^{\circ}, 90^{\circ}$ & 13 & $16^{\circ}$ & -2.5 & Owl Creek Mtns. \\
\hline 39 & Vein & $1^{\circ}, 90^{\circ}$ & 20 & $170^{\circ}$ & -4.7 & Black Hills \\
\hline 40 & Vein & $0^{\circ}, 0^{\circ}$ & 0 & $352^{\circ}, 5^{\circ}$ & -2.1 & N. Black Hills \\
\hline 41 & Vein & $10^{\circ}, 90^{\circ}$ & 18 & $200^{\circ}, 40^{\circ}$ & -8.5 & E. Black Hills \\
\hline 42 & Vein & $30^{\circ}, 90^{\circ}$ & 8 & $5^{\circ}, 10^{\circ}$ & -3.6 & E. Black Hills \\
\hline 43 & Vein & $98^{\circ}, 90^{\circ}$ & 22 & $165^{\circ}, 70^{\circ}$ & -6.8 & SE Black Hills \\
\hline \multicolumn{7}{|c|}{ Laramide Basins } \\
\hline 44 & Cement & None & 0 & $168^{\circ}$ & -2.1 & Derby Dome ${ }^{f}$ \\
\hline 45 & Vein & $0^{\circ}, 90^{\circ}$ & 0 & $162^{\circ}, 1^{\circ}$ & -2.6 & Derby Dome ${ }^{f}$ \\
\hline 46 & Vein & Horizontal & 5 & $6^{\circ}, 4^{\circ}$ & -3.4 & Derby Dome $^{\mathrm{f}}$ \\
\hline 47 & Vein & $320^{\circ}, 90^{\circ}$ & 11 & $186^{\circ}$ & -1.77 & Derby Dome ${ }^{f}$ \\
\hline 48 & Cement & None & 18 & $95^{\circ}, 55^{\circ}$ & -1.7 & Wind River basin folds ${ }^{\mathrm{d}}$ [\#29] \\
\hline
\end{tabular}


Table 2 (continued)

\begin{tabular}{|c|c|c|c|c|c|c|}
\hline Sample & Cement or vein & Strike and dip & $\begin{array}{l}\text { NEVs } \\
(\%)\end{array}$ & $\begin{array}{l}e 1 \text { trend/plunge } \\
\left({ }^{\circ}\right)\end{array}$ & $\begin{array}{l}e 1 \\
(\%)\end{array}$ & Comment \\
\hline 49 & Cement & None & 6 & $220^{\circ}, 50^{\circ}$ & -2.1 & Wind River basin folds ${ }^{\mathrm{d}}[\# 26]$ \\
\hline 50 & Cement & None & 6 & $255^{\circ}, 5^{\circ}$ & -5.9 & Wind River basin folds ${ }^{\mathrm{d}}[\# 24]$ \\
\hline 51 & Cement & None & 16 & $350^{\circ}, 20^{\circ}$ & -3.2 & Wind River basin folds ${ }^{\mathrm{d}}[\# 22]$ \\
\hline 52 & Cement & None & 6 & $305^{\circ}, 20^{\circ}$ & -7 & Wind River basin folds ${ }^{\mathrm{d}}[\# 21]$ \\
\hline 53 & Cement & None & 6 & $215^{\circ}, 70^{\circ}$ & -3.7 & Wind River basin folds ${ }^{\mathrm{d}}[\# 20]$ \\
\hline 54 & Cement & None & 24 & $0^{\circ}, 80^{\circ}$ & -2.2 & Wind River basin folds ${ }^{\mathrm{d}}[\# 17]$ \\
\hline 55 & Cement & None & 8 & $80^{\circ}, 0^{\circ}$ & -4.1 & Wind River basin folds ${ }^{\mathrm{d}}[\# 16]$ \\
\hline 56 & Cement & None & 11 & $275^{\circ}, 15^{\circ}$ & -3.2 & Wind River basin folds ${ }^{\mathrm{d}}[\# 11]$ \\
\hline 57 & Cement & None & 11 & $150^{\circ}, 20^{\circ}$ & -1.9 & Wind River basin folds ${ }^{\mathrm{d}}[\# 6]$ \\
\hline 58 & Cement & None & 12 & $125^{\circ}, 45^{\circ}$ & -2.8 & Wind River basin folds ${ }^{\mathrm{d}}[\# 4]$ \\
\hline
\end{tabular}

a Craddock, 1992: Nos. 1-16, 25-27.

${ }^{\mathrm{b}}$ Craddock and van der Pluijm, 1988.

${ }^{\mathrm{c}}$ Budai and Wiltschko, 1987.

${ }^{\mathrm{d}}$ Willis and Groshong, 1993.

e Neilson et al., 1997.

${ }^{\mathrm{f}}$ Relle and Craddock, 1997.

${ }^{g}$ Carson, 1988.

syn-folding strains preserved in younger calcite cements (Relle and Craddock, 1997). In contrast, twins in vein calcite record a regional, sub-horizontal NS-shortening strain, regardless of the vein orientation (Table 2, Fig. 1b,d).

\subsection{Western U.S. continental interior}

Three samples were analyzed from the Cretaceous Greenhorn Limestone in western Minnesota near Brown's Valley at the southeast end of Traverse Lake (Fig. 1a,c). The Greenhorn Limestone is a flat-lying, fossiliferous, chalky limestone that is locally sparry and devoid of younger calcite veins. Twinned calcite in these rocks, which are the easternmost exposures of Cretaceous carbonates in the Cretaceous seaway, preserves a consistent, E-W LPS fabric. Greenhorn Limestone samples from the eastern Black Hills, unfortunately, are too micritic to allow calcite twinning analysis.

\subsection{Adjacent tectonic provinces: \\ Appalachian-Ouachita thrust belt and eastern continental interior}

The easternmost portion of our study area (Minnesota) also contains Paleozoic limestones that, in places, underlie Cretaceous sediments. Notably, the
LPS fabric in the Paleozoic limestones is oriented roughly perpendicular to the E-W Sevier fabric, and preserves a regional shortening strain associated with the Appalachian-Ouachita orogen $>1500 \mathrm{~km}$ from the orogenic front (Craddock et al., 1993). Six of our earlier strain analyses are included for comparison (Table 1, Fig. 1a,c).

\subsection{Keweenawan rift province}

The Keweenawan rift was active at about $1.1 \mathrm{Ga}$, and later closed along thrust faults (Douglas and Keweenawan faults) of opposite dip and displacement on both sides of the rift (e.g., Dickas, 1985; Cannon, 1994). The rift is filled with a thick sequence of basalts, most of which are amygdaloidal and fractured. The fractures and vesicles are commonly filled with calcite, which is everywhere twinned. Strain analysis in six sites documented subhorizontal shortening strains that are rift-parallel (NE-SW) for the older amygdule fillings and rift-normal (SE-NW) for the younger calcite veins (Craddock et al., 1997). This strain fabric is distinct from the LPS twinning strain pattern preserved in the Paleozoic carbonates adjacent to (Upper Peninsula, Michigan) or overlying (southern Minnesota and Iowa) the Keweenawan rift (Fig. 1b, d; Table 2). 


\subsection{Kenora-Kabetogama dike margins}

In Proterozoic times, the southern margin of the North American craton underwent extensive crustal shortening known as the Penokean orogen, which is represented by deformed basinal (e.g., Marquette Supergroup) and foreland (e.g., Animikie basin) sediments, regional Andean-style magmatism, marginnormal mafic dike swarms, regional metamorphism, and tectonic suturing (Sims, 1976). The KenoraKabetogama dike swarm (Southwick and Day, 1983) on the northern margin of the Penokean suture in Minnesota and Ontario is dated at $2.076 \mathrm{Ga}$ (Wirth and Vervoort, 1995), and is interpreted as a prePenokean margin-normal dike swarm (Schmitz et al., 1995) that is part of a regional strike-slip fault-fracture array cross-cutting the Archean crust (Craddock and Moshoian, 1995). The dike margins commonly contain interbedded calcite veins and calcite-rich pseudotachylyte, which have recorded dike-parallel, sub-horizontal shortening directions (Fig. 1b,d; Kropf et al., 1993).

\section{Discussion}

\subsection{Tectonic dimensions}

Mesozoic-early Cenozoic deformation of the western margin of North America is characterized by the formation of the Idaho-Wyoming fold-andthrust belt (Wiltschko and Dorr, 1983), the proximal Green River foreland basin (Dorr et al., 1977; Jordan, 1981), and the distal foreland basins and Laramide crystalline uplifts (Gries, 1983; Schedl and Wiltschko, 1983; Oldow et al., 1989). The older, thin-skinned Sevier portion of the deformation occurred near the margin with thrust translation directed eastward, whereas the younger, basement-involved Laramide uplifts and basins localized within continental North America reflect crustal shortening generally directed to the ENE (see Gries, 1983 and Bird, 1988). The Sevier shortening is preserved as a regional LPS calcite strain fabric, which is present as far east as Minnesota in the Cretaceous Greenhorn Limestone. This represents stress transfer of $>2000 \mathrm{~km}$ from the restored thrust margin in Idaho (van der Pluijm et al., 1997). Strain mag- nitude varies along this transect, where correlation of differential stress and twinning strain magnitude is hampered by lithologic, grain size and porosity variations in the limestones across the region.

Deformation in the region is also recorded by various calcite fillings, namely cements and crosscutting synorogenic veins. In the thrust belt, calcite veins record a complex deformation history that is associated with local piggyback thrust motions (Fig. 1d, inset; Craddock, 1992). This strain complexity is also found in the twinning strains recorded in flank fold structures in the Wind River basin (Willis and Groshong, 1993; Relle and Craddock, 1997; Table 1). However, calcite veins in Laramide uplifts preserve a distinctive sub-horizontal, $\mathrm{N}-$ S-shortening strain, suggesting a dramatic shift in the orientation of regional compressive stresses along the margin of western North America in the early Tertiary (Fig. 2).

\subsection{Collisional and transpressive orogenic stresses}

The final continent-continent collision that formed Pangea in late Paleozoic times had a subtle yet measurable impact on the foreland of the Appalachian-Ouachita mountain belt. Transmission of compressive stresses from this orogen extended regionally (Craddock et al., 1993), similar to distances observed in, for example, the present-day India-Asia collision (Tapponier et al., 1986; Zoback, 1992).

The Sevier-Laramide orogen is similar in style and evolution to the present-day Andean margin, in that the younger Laramide structures are considered a crustal response to shallowing slab dip, perhaps as the continental margin became more transpressive (Monger et al., 1982). Oblique convergence along the western margin of North America has been modeled by Bird (1988) (see also Mount and Suppe, 1987), and these modeling results generally agree with our Sevier (E-W shortening) and Laramide $(\sim \mathrm{N}-\mathrm{S}$ shortening) calcite twinning data.

\subsection{Contemporaneous stress fields in the Sevier-Laramide foreland}

The roughly E-W calcite shortening fabric orientation in the western continental interior is parallel to the principal compressive stress $\left(S_{\mathrm{Hmax}}\right)$ of 
Sevier Orogen (140-90 Ma)

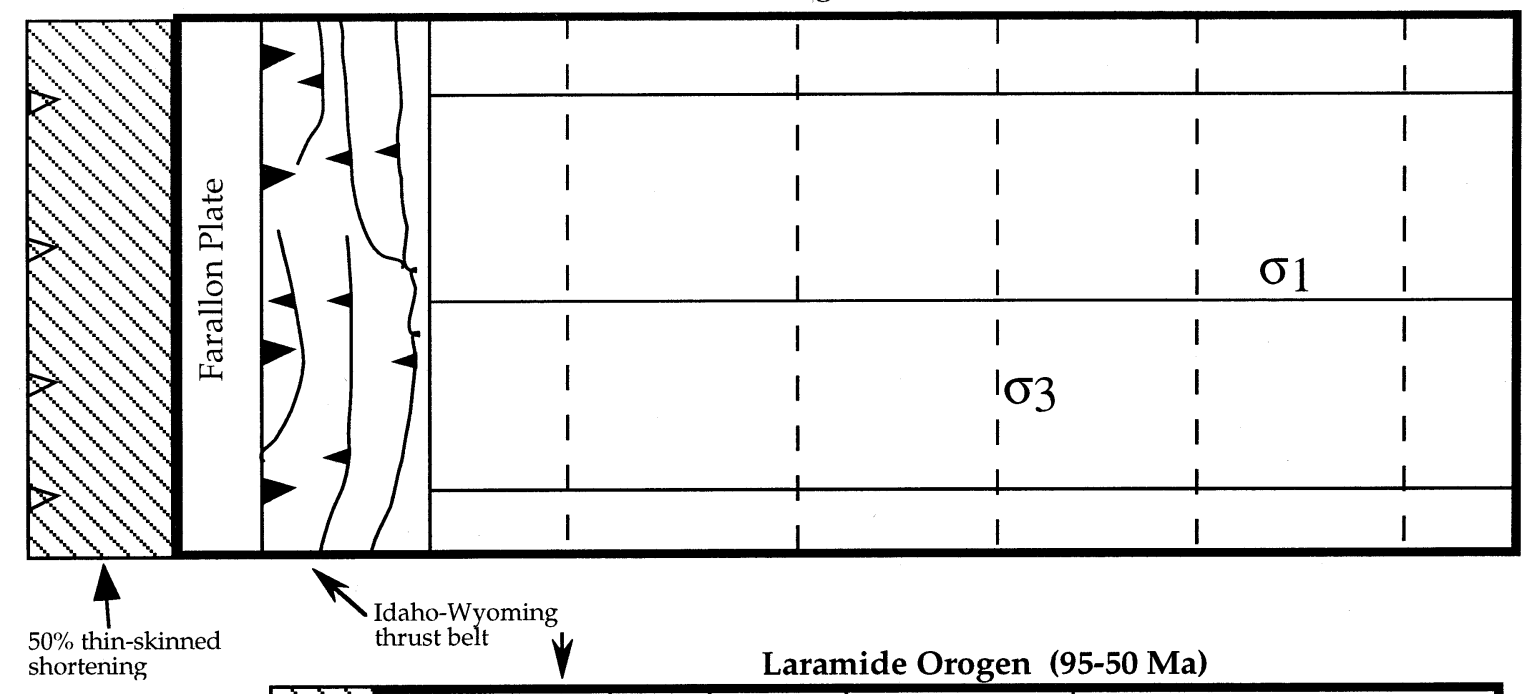

$30 \%$ thick-skinned shortening

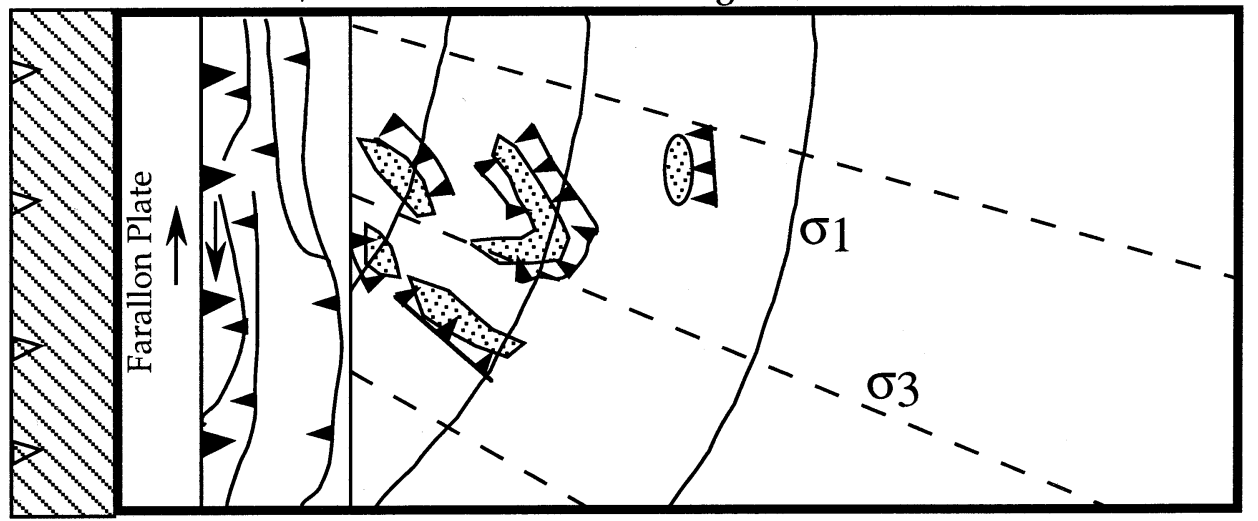

Fig. 2. Diagrammatic representation of the principal compression axes preserved for (top) country rock samples (Sevier orogen; $50 \%$ shortening, Craddock, 1992) when margin-normal subduction dominated the foreland, and (bottom) vein shortening axes (Laramide orogen; 30\% shortening, Gries, 1983) where oblique convergence and shallow slab-dip dominated.

today's stress field (McGarr and Gay, 1978; Richardson et al., 1979; Zoback, 1992), but is distinct from (Laramide) $\sim \mathrm{N}-\mathrm{S}$ shortening recorded by synorogenic calcite veins within the region. The absence of any overprint by the contemporaneous stress field in our calcite twinning data (i.e., a high percentage of NEVs would be expected but is absent) can be interpreted in terms of the low differential stress magnitude of today's field relative to the burial depths of our samples (Ferrill, 1998), and/or how much calcite strain-hardens once it twins (Teufel, 1980). Moreover, within the Idaho-Wyoming thrust belt, which is on the margin of active Basin and Range extension (e.g., Teton, Star Valley and Grand Valley nor- mal faults), there is no extensional strain overprint recorded in the calcite. There are, however, Tertiaryage $\mathrm{E}-\mathrm{W}$ mafic dike swarms in the thrust belt (Dorr et al., 1977) and E-W clastic dikes that crosscut NS-trending folds in Cretaceous-Tertiary sediments as far east as the Badlands in South Dakota (Raymond and King, 1976), suggesting an upper age bracket for the initiation of the present-day stress field.

\section{Conclusions}

Bedding-parallel, subhorizontal shortening strains, as preserved by twinned calcite in Cambrian-Creta- 
ceous carbonates that cover cratonic western North America, are perpendicular to the orogenic front of the Sevier belt. These thrust-transport parallel fabrics extend $>2000 \mathrm{~km}$ into the plate interior, and were caused by the transmission of compressive MesozoicCenozoic orogenic stresses at the plate margin. The magnitudes of the twinning paleostresses decrease exponentially away from the active plate margin. Twinning strain values also decrease toward the craton, although this pattern is less consistent due to variations in lithology, grain size, porosity, etc. Analysis of twinning strains in syn-thrusting calcite veins reveals a complex, local strain history in the thrust belt, and a regionally consistent $\mathrm{N}-\mathrm{S}$ sub-horizontal shortening fabric in Laramide uplifts and basins. The latter pattern marks a change in stress field orientation during oblique convergence at the plate margin during the Laramide orogen, perhaps associated with a degree of plate coupling.

\section{Acknowledgements}

This research was supported by the Pew Charitable Trust, the Blandin Foundation, the Huron Mountain Wildlife Foundation, and by NSF grant EAR 90-04181 to Craddock. Field support was cheerfully provided by Greg Miller, Andrew Moshoian, Alene Pearson, Michelle McGovern, Annie and Cara Craddock, and in part, by the University of Missouri Branson Field Station. Lab assistance from Andrea Troolin and Monica Relle is greatly appreciated. Reviews by Rick Groshong and Dave Ferrill improved the clarity of the manuscript.

\section{References}

Allmendinger, R.W., 1982. Analysis of microstructures in the Meade plate of the Idaho-Wyoming foreland thrust belt, USA. Tectonophysics 85, 221-251.

Anderson, R.R., 1988. Phanerozoic structural features in the northern Midcontinent, USA, scale 1: 1,000,000, U.S. Geol. Surv. Misc. Field Stud. Map, MF-1835-E.

Apotria, T.G., 1990. The Kinematics and Mechanics of Oblique Ramp Deformation within Fold-and-Thrust Belts. Ph.D. dissertation, Texas A and M University, College Station, TX, 235 pp.

Apotria, T.G., 1995. Thrust sheet rotation and out-of-plane straqins associated with oblique ramps: an example from the
Wyoming salient, USA. J. Struct. Geol. 17, 647-662.

Bird, P., 1988. Formation of the Rocky Mtns., western United States: a continuum computer model. Science 239, 15011507.

Budai, J.M., Wiltschko, D.V., 1987. Structural controls on syntectonic diagenesis within the Haystack Peak region of the Absaroka thrust sheet, Idaho-Wyoming-Utah thrust belt. 38th W.G.A. Field Conference Guidebook, pp. 55-68.

Burkhard, M., 1993. Calcite twins, their geometry, appearance and significance as stress-strain markers and indicators of tectonic regime: a review. J. Struct. Geol. 15, 351-368.

Cannon, W.F., 1994. Closing of the Midcontinent rift - a far-field effect of Grenvillian compression. Geology 22, 155158.

Carson, D.W., 1988. A Regional Analysis of Calcite Twinning Strain in the Bighorn Mountains, N. Wyoming. M.S. thesis, Iowa State University, $71 \mathrm{pp}$.

Craddock, J.P., 1992. Transpression during tectonic evolution of the Idaho-Wyoming fold-and-thrust belt. Geol. Soc. Am. Mem. 179, 125-139.

Craddock, J.P., Moshoian, A., 1995. Continuous strike-slip faulten echelon fracture arrays in deformed Archean rocks: implications for fault propagation mechanics. In: Ojakangas, R.J. et al. (Eds.), Basement Tectonics, Vol. 10, Kluwer, Netherlands, pp. 379-407.

Craddock, J.P., Pearson, A., 1994. Non-coaxial horizontal shortening strains preserved in amygdule calcite, DSDP Hole 433C, Suiko Seamount. J. Struct. Geol. 16, 719-724.

Craddock, J.P., van der Pluijm, B.A., 1988. Kinematic analysis of an en echelon-continuous vein complex. J. Struct. Geol. 10, 445-452.

Craddock, J.P., van der Pluijm, B.A., 1989. Late Paleozoic deformation of the cratonic carbonate cover of eastern North America. Geology 17, 416-419.

Craddock, J.P., Kopania, A., Wiltschko, D.V., 1988. Interaction between the northern Idaho-Wyoming thrust belt and bounding basement blocks, central western Wyoming. Geol. Soc. Am. Mem. 171, 333-351.

Craddock, J.P., Moshoian, A., Pearson, A.M., 1991. Kinematic analysis from twinned calcite strains in the marble mylonites of the central Grenville province, Canada. Geol. Soc. Am. Abstr. Prog. 15, 236.

Craddock, J.P., Jackson, M., van der Pluijm, B., Versical, R., 1993. Regional shortening fabrics in eastern North America: far-field stress transmission from the Appalachian-Ouachita orogenic belt. Tectonics 12, 257-264.

Craddock, J.P., Pearson, A., McGovern, M., Moshoian, A., Donnelly, K., 1997. Post-extension shortening strains preserved in calcites of the Keweenawan rift. Geol. Soc. Am. Mem. 312, 115-126.

Davis, D., Engelder, T., 1985. The role of salt in fold-and-thrust belts. Tectonophysics 119, 67-88.

Dickas, A., 1985. Comparative Precambrian stratigraphy and structure along the Mid-continent rift. Bull. Am. Assoc. Pet. Geol. 70, 225-238.

Dorr, J.A., Jr., Spearing, D.R., Steidtmann, J.R., 1977. Deformation and deposition between a foreland uplift and an impinging 
thrust belt, Hoback basin, Wyoming. Geol. Soc. Am. Spec. Pap. 177, 82 pp.

Engelder, T., 1979a. The nature of deformation within the outer limits of the central Appalachian foreland fold-and-thrust belt in New York state. Tectonophysics 55, 289-310.

Engelder, T., 1979b. Mechanisms of strain within the Upper Devonian clastic sequence of the Appalachian Plateau western New York. Am. J. Sci. 279, 527-542.

Engelder, T., 1993. Stress Regimes in the Lithosphere. Princeton Univ. Press, Princeton, NJ, 457 pp.

Engelder, T., Engelder, P., 1977. Fossil distortion and decollement tectonics of the Appalachian Plateau. Geology 5, 457460.

Engelder, T., Geiser, P., 1980. On the use of regional joint sets as trajectories of paleostress fields during the development of the Appalachian Plateau, New York. J. Geophys. Res. 85, 63196341.

Ferrill, D.A., 1991. Calcite twin widths and intensities as metamorphic indicators in natural low-temperature deformation of limestone. J. Struct. Geol. 13, 667-675.

Ferrill, D.A., 1998. Critical re-evaluation of differential stress estimates from calcite twins in coarse-grained limestone. Tectonophysics $285,77-86$.

Gasteiger, C.M., 1980. Strain Analysis of a Low Amplitude Fold in North-Central Oklahoma Using Calcite Twin Lamellae. M.S. thesis, University of Oklahoma, Norman, 90 pp.

Geiser, P., Engelder, T., 1983. The distribution of layer-parallel shortening fabrics in the Appalachian foreland of New York and Pennsylvania: evidence for two non-coaxial phases of the Alleghenian orogeny. Geol. Soc. Am. Mem. 158, 161-176.

Gries, R., 1983. Oil and gas prospecting beneath Precambrian of foreland thrust plates in Rocky Mtns. Bull. Am. Assoc. Pet. Geol. 67, 1-28.

Groshong Jr., R.H., 1972. Strain calculated from twinning in calcite. Bull. Geol. Soc. Am. 83, 2025-2038.

Groshong Jr., R.H., 1974. Experimental test of least-squares strain calculations using twinned calcite. Bull. Geol. Soc. Am. $85,1855-1864$.

Groshong Jr., R.H., 1975. Strain, fractures, and pressure solution in natural single-layer folds. Bull. Geol. Soc. Am. 86, 13631376.

Groshong Jr., R.H., Teufel, L.W., Gasteiger, C.M., 1984. Precision and accuracy of the calcite strain-gage technique. Bull. Geol. Soc. Am. 95, 357-363.

Gwinn, V.E., 1964. Thin-skinned tectonics in the Plateau and northwestern Valley and Ridge provinces of the central Appalachians. Geol. Soc. Am. Bull. 75, 863-899.

Hennings, P., 1986a. Petrofabric implications for cover rock adjustment in basement-cored anticline: Dry Fork Ridge, Bighorn Mtns., Wyoming. Geol. Soc. Am. Abstr. Prog. 18 (6), 635 .

Hennings, P., 1986b. Basement-Cover Relations of the Dry Fork Ridge Anticline Termination, Northeastern Bighorn Mountains, Wyoming and Montana. M.S. thesis, Texas A and M University, College Station, TX, 187 pp.

Jackson, M., Craddock, J.P., Ballard, M., Van Der Voo, R., McCabe, C., 1989. Anhysteretic remanent magnetic anisotropy and calcite strains in Devonian carbonates from the Appalachian Plateau, New York. Tectonophysics 161, 43-53.

Jamison, W.R., Spang, J.H., 1976. Use of calcite twin lamellae to infer differential stress. Geol. Soc. Am. Bull. 87, 868-872.

Jordan, T.E., 1981. Thrust loads and foreland basin evolution, Cretaceous, western United States. Bull. Am. Assoc. Pet. Geol. 65, 2506-2520.

Kilsdonk, W., Wiltschko, D.V., 1988. Deformation mechanisms in the southeastern ramp region of the Pine Mountain block, Tennessee. Geol. Soc. Am. Bull. 100, 653-664.

Kraig, D.H., Wiltschko, D.V., 1987. Effects on the calcite fabric (Madison Fm.) of the impingement of the Darby/Hogsback thrust sheet and LaBarge Platform, Snider Basin area. Wyoming Geol. Assoc. 38th Guidebook.

Kraig, D.H., Wiltschko, D.V., Spang, J.H., 1987. Interaction of basement uplift and thin-skinned thrusting, Moxa Arch and the Western Overthrust belt, Wyoming. Geol. Soc. Am. Bull. 99, 654-662.

Kropf, E.P., Craddock, J.P., Wirth, K.R., 1993. Calcite-bearing pseudotachylite in Archean amphibolite-grade rocks along the Great Lakes tectonic zone. Eos 74 (43), 577.

Lancome, O., Laurent, P., 1996. Determination of deviatoric stress tensors based on inversion of calcite twin data from experimentally deformed monophase samples: preliminary results. Tectonophysics 255, 189-202.

McGarr, A., Gay, N.C., 1978. State of stress in the Earth's crust. Annu. Rev. Earth Planet. Sci. 6, 405-436.

Monger, J.W.H., Price, R.A., Templeman-Kluit, D.J., 1982. Tectonic accretion and the origin of the two major metamorphic and plutonic welts in the Canadian Cordillera. Geology 10, $70-75$

Mount, V., Suppe, J., 1987. State of stress near the San Andreas Fault: implications for wrench tectonics. Geology 15, 11431146.

Neilson, K.J., Craddock, J.P., Malone, D.H., 1997. Calcite twinning strains and magnetic fabric constraints on the Heart Mountain detachment. Geol. Soc. Am. Abstr. Prog. 29 (4), 63.

Nickelson, R.P., 1966. Fossil distortion and penetrative rock deformation in the Appalachian Plateau. J. Geol. 74, 924-931.

Oldow, J.S., Bally, A.W., Avé Lallement, H.G., Leeman, W.P., 1989. Phanerozoic evolution of the North American Cordillera; United States and Canada. In: Bally, A.W., Palmer, A.R. (Eds.), The Geology of North America - An Overview. Geol. Soc. Am., Boulder, CO, DNAG Vol. A, pp. 139-232.

Onasch, C.M., Kahle, C.F., 1991. Recurrent tectonics in a craton setting: an example from northeastern Ohio. Geol. Soc. Am. Bull. 103, 1259-1269.

Raymond, W.H., King, R.U., 1976. Geology of the Badlands, S. Dakota. U.S.G.S Map I-934.

Relle, M., Craddock, J.P., 1997. Incremental stress and strain fields in the Laramide Derby dome fold, Wind River basin, WY. Geol. Soc. Am. Abstr. Prog. 29 (4), 68.

Richardson, R.M., Solomon, S.C., Sleep, N.H., 1979. Tectonic stress in the plates. Rev. Geophys. Space Phys. 17, 981-1019.

Rodgers, J., 1963. Mechanics of Appalachian foreland folding in Pennsylvania and West Virginia. Bull. Am. Assoc. Pet. Geol. 47, 1527-1536. 
Rowe, K.J., Rutter, E.H., 1990. Paleostress estimation using calcite twinning: experimental calibration and application to nature. J. Struct. Geol. 12, 1-17.

Schedl, A., Wiltschko, D.V., 1983. Sedimentological effects of a moving terrain. J. Geol. 92, 273-287.

Schmitz, M.D., Wirth, K.R., Craddock, J.P., 1995. Major and trace element geochemistry of early Proterozoic mafic dykes of northern Minnesota and southwestern Ontario. In: Baer, G., Heimann, A. (Eds.), Physics and Chemistry of Dykes. Balkema, Rotterdam, pp. 219-236.

Sims, P.K., 1976. Precambrian tectonics and mineral deposits, Lake Superior region. Econ. Geol. 71, 1092-1127.

Southwick, D.L., Day, W.C., 1983. Geology and petrology of Proterozoic mafic dikes, north-central Minnesota and western Ontario. Can. J. Earth Sci. 20, 622-638.

Spang, J.H., Groshong Jr., R.H., 1981. Deformation mechanisms and strain history of a minor fold from the Appalachian Valley and Ridge Province. Tectonophysics 72, 323-342.

Tapponier, P., Peltzer, G., Armijo, R., 1986. On the mechanics of the collision between India and Asia. Geol. Soc. London Spec. Publ. 19, 115-157.

Teufel, L.W., 1980. Strain analysis of experimental superposed deformation using calcite twin lamellae. Tectonophysics 65 , 291-309.

Turner, F.J., 1953. Nature and dynamic interpretation of deformation lamellae in calcite of three marbles. Am. J. Sci. 251, 276-298. van der Pluijm, B.A., Craddock, J.P., Graham, B.R., Harris, J.H., 1997. Paleostress in cratonic North America: implications for deformation of continental interiors. Science 277, 792-796.

Varga, R.J., 1993. Rocky Mtn. foreland uplifts: products of a rotating stress field or strain partitioning? Geology 21, 11151118.

Willis, J.J., Groshong, R.H., Jr., 1993. Deformational style of the Wind River uplift and associated flank structures, Wyoming. Wyo. Geol. Assoc. Symp. Guidebook, pp. 337-375.

Wiltschko, D.V., Chapple, W., 1977. Flow of weak rocks in Appalachian Plateau folds. Bull. Am. Assoc. Pet. Geol. 65, 653-670.

Wiltschko, D.V., Dorr, J.A., 1983. Timing of deformation in the overthrust belt of Idaho, Wyoming and Utah. Bull. Am. Assoc. Pet. Geol. 67, 1304-1322.

Wiltschko, D.V., Medwedeff, D.A., Millson, H.E., 1985. Distribution and mechanisms of strain within rocks on the northwest ramp of Pine Mountain block, southern Appalachian foreland: a field test of theory. Geol. Soc. Am. Bull. 96, 426-435.

Wirth, K.R., Vervoort, J.D., 1995. Nd isotopic constraints on mantle and crustal contributions to Early Proterozoic dykes of the southern Superior province. In: Baer, G., Heimann, A. (Eds.), Physics and Chemistry of Dykes. pp. 237-250.

Zoback, M.L., 1992. First and second-order patterns of stress in the lithosphere: the World Stress Map project. J. Geophys. Res. 97, 11703-11728. 